\title{
Corruption and Trade
}

\author{
Muhammad Tariq Majeed \\ Quaid-i-Azam University, Islamabad, Pakistan
}

\begin{abstract}
Using a panel data set for 146 countries over the period 1984 2007, this study contributes in the area of trade-corruption linkages by highlighting the non-monotonic relationship between trade and corruption and significance of complementary policy reforms in shaping the link. Findings of the study suggest that trade increases corruption in a linear specification while its effect on corruption decreasing in a non-linear specification. The analysis exhibits that this non-linear nature of the relationship is worth noting and help answering the question why the literature on the relationship between trade and corruption is not conclusive. Furthermore, we make argument and find empirical support to our proposition that this is not just openness to trade that can reduce corruption but there are complimentary policy reforms that cause a decline in corruption. Findings of the study are robust to alternative specifications, econometric techniques, control of nonlinearity, control of interactive effects, and exclusion of outliers.
\end{abstract}

\footnotetext{
* Corresponding Author: Muhammad Tariq Majeed; Department of Economics, School of Economics, Quaid-iAzam University, Islamabad 44000, Pakistan; Pakistani; Tel: +92 05190643020, E-mail:tariq@qau.edu.pk.

\begin{abstract}
Acknowledgement: I wish to thank an anonymous referee and the editor of this journal for helpful comments and suggestions. All errors and omissions remain mine. An initial draft of this study has been benefited from the comments received from a presentation in the Workshop: International Political Economy and Cross-Border Effects, at Goodenough College organized by Centre for Globalization Research (CGR) School of Business and Management, Queen Marry University of London, April 28, 2011, London, UK. The presentation of this study has been benefitted from a travel grant from the Business School of the University of Glasgow, UK.
\end{abstract}


JEL Classification: C23, D73, F14, K42, H10

Keywords: Corruption, Law, Openness To Trade, Panel Data

\section{Introduction}

Corruption is disliked for its detrimental effects on economic growth and development. It inhibits the provision of public services, increases inequalities and stifles investments to such an extent that the World Bank has declared it as the single greatest obstacle to economic and social development (World Bank 2001). Control of corruption and the promotion of fairness in the markets are at the core of development strategies.

What causes corruption? Why does corruption exist everywhere around the world? Research on the causes of corruption has proliferated in recent years and has identified many factors such as economic, political, cultural, and institutional aspects. While many studies have explored institutional and cultural causes of corruption, a small body of the literature has focused on the nature of corruption in an open economy (Krueger 1974, Ades and Di Tella 1999, Wei 1999, Gatti 2004). These studies report a negative effect of economic openness on corruption.

However, some studies point out a positive relationship between trade and corruption as well. For instance, Ades and Di Tella (1999) predict ambiguous effects of foreign competition on corruption. On the one hand, a lower degree of foreign competition increases rents and provide more opportunities for corruption. While on the other hand, in this situation, it becomes more valuable for a society to avoid corruption and to increase the accountability and monitoring of its bureaucracy. In an empirical study, Treisman (2000) argues that opportunities for corruption are likely to rise in the presence of trade liberalization. He further argues that extensive trade liberalization can help to reduce corruption.

The existing literature on trade-corruption relationship focuses linear and noninteractive effects of trade on corruption. This study adds to the existing literature by examining the non-linear and interactive nature of the trade-corruption relationship. Three key questions addressed are: (i) what are the effects of the trade openness on corruption? (ii) Is the relationship between trade and corruption non-monotonic? (iii) What are the interactive effects of trade and domestic policy reforms? 
Rest of the discussion is organized as follows. Section II provides a review of the literature. Section III briefly describes the data and Section IV provides an analytical framework for the study. Section V provides results and discussion. Finally, Section VI concludes.

\section{Literature Review}

This section reviews the relevant literature to understand the mechanism which builds a relationship between trade openness and corruption. In particular, it addresses the question: why and how trade openness determines corruption in a country. To this end, rent seeking literature provides the base to derive and construct sound theoretical linkages between trade and corruption.

The expression, rent-seeking, was coined in 1974 by Anne Krueger. This expression implies that extraction of uncompensated value from others without making any contribution to productivity. In market-oriented economies, government restrictions upon economic activities generate rents in different forms such as bribery, smuggling, and black markets. Since bureaucrats have discretionary authority for awarding legitimate or illegitimate benefits to clients, they are likely to extract bribe or rent for applying their legal but discretionary authority.

Krueger (1974) develops the first mechanism between trade and rent seeking activities. The quantitative restrictions on imports (in contrast to tariff, quota and other official permissions to imports) entitle monopolistic powers to legal importers and, therefore, generate opportunities for economic rent seeking activities. Agents may legally compete or illegally seek rent-seeking activities such as smuggling, black market, bribery, and corruption to exploit these opportunities. Krueger shows that such rent seeking activities create deviation between social and private costs and forces an economy to operate at a sub-optimal level. Thus, an economy incurs a welfare cost in addition to the trade restrictions.

In successive academic papers, Bhagwati and Srinivasan (1980) and Bhagwati (1982), have extended Krueger's concept of rent seeking activities to a whole array of Directly Unproductive Profit-seeking (DUP), providing further arguments in favor of the free trade. Recently Gatti (1999) describes two effects of inward looking policies 
on corruption. (i) Direct policy distortion which implies that high barriers to free trade create incentives for private agents to seek favoritism from public officials offering bribes. (ii) Foreign competition effect implies that high restrictions to free trade decrease competition between domestic and foreign firms, thereby leaving margins for rent seeking activities and corruption.

Ades and Di Tella (1999), provide further insights on corruption-rent seeking mechanism. They present evidence that the level of rents in general and market structure in particular, determine the intensity of corruption in an economy. They argue that variation in rent size as a result of changes in competition causes ambiguous effects on corruption. On the one hand, lower levels of competition provide opportunities to bureaucrats to extract more rents from the firms they control. On the other hand, this situation also implies that it is more valuable for the society to avoid corruption and increase the accountability and monitoring of its bureaucracy. Theoretically, net impact of competition on corruption is ambiguous. Therefore, determination of the net impact remains an empirical issue.

Real world exhibits some examples of possible association between rent and corruption. For instance, Nigeria provides a striking example of positive association between rents and corruption. In 1980s, oil exports of Nigeria generated $80 \%$ of government revenue and created extraordinary opportunities for corruption. Evidence of their study suggests that corruption is higher in countries where domestic firms are less exposed to foreign competition or countries with concentrated exports.

Wei (2000) advances another mechanism to explain the relationship between trade and corruption by taking into account costs and benefits of monitoring government officials. He argues that quality of institutions and their capacity to combat corruption crucially depend on the resources a country allocates to this end. A country invests more to improve the quality of such domestic institutions when benefits outweigh the costs.

Since international investors and traders can easily divert their businesses from one country to another than domestic ones, corruption and bad governance discourage business decisions of foreign stakeholders more strongly compared to domestic ones. International investors enjoy stronger bargaining power relative to domestic procedures. Furthermore, enforcement costs for international contracts increase more steeply with bad governance. Such a diverse effect of corruption between domestic and foreign stakeholders justifies strong corruption reducing policies in relatively more open economies. Given the stakes of such large benefits, an economy that is more exposed to international markets would find it optimal to allocate more resources to building good 
institutions and end up with a lower level of corruption than a less open, inward looking one.

Torrez (2002) examines the relationship between trade and corruption to test the argument that restricted trade shifts resources from productive activities to rent-seeking activities. The study shows that a negative relationship holds for most of the empirical evidence, but this relationship is not robust.

Evidence on positive relationship between trade openness and corruption were initially observed in transitional economies of Eastern Europe and former the Union of Soviet Socialist Rebublic (USSR), where essential steps to privatize the economy and rewrite the rules of commerce after the demise of socialism were often accompanied by widespread corruption (Transparency International 2005, p.271).

Trade liberalisation introduces and increases imports of new goods and services. The availability of a variety of imports increases the marginal utility of income of consumers if they have a desire for a variety of goods. This effect is likely to be more significant in developing countries which lack the ability to produce a wide variety of goods and services domestically. Similarly, increased imports of different goods increase the marginal utility of bribe income for custom officials, thereby increasing incentives for bribe-seeking.

Trade openness may also generate new opportunities for corruption. Tanzi (1998) reports that trade liberalisation has created new opportunities for corruption as paying bribes gives advantages in obtaining foreign contracts or privileged access to markets, or some specific gains such as tax incentives. Paying bribes maximises the mutual interests of politicians and firms. Politicians want to stay in office by re-election and to do this, they need money to finance their campaigns, while firms need business incentives. Thus, politicians have an incentive to award contracts or other benefits to those firms that pay them bribes.

Small countries trade more as they produce fewer goods internally. In an open economy, market discipline improves governance. However, this argument is not necessarily true as it ignores the possibility that small size increases the per capita rent, which motivates custom officials to extract more bribes. Therefore, greater openness could lead to a higher incidence of corruption.

It is usually considered that corruption is explained by domestic factors. Since corruption is an outcome of demand and supply, foreign demand for corrupt acts, other than domestic factors, can also affect the level of corruption in an importing country. Hisamatsu (2003) contributes to the literature on corruption and trade by testing the 
proposition that countries trading with corrupt countries also import corruption. The empirical findings of his study confirm the proposition.

Yarbrough and Yarbrough (1990) analyze the role of preferential trade agreements in shaping the relationship between economic integration and governance. They argue that preferential trade agreements can reduce opportunistic behavior by providing organizational structure. Jovanovic (2010) argue that there were once hopes that globalization would benefit everyone. As time passes, downside of globalization becomes more and more apparent. In a recent study, Suzuki (2013) shows that the intensity of trade and imports from the EU during 1984 2009 reduced the corruption level in African countries, but not always the intensity of exports to the EU.

Recently, the role of policy complementarities is attracting a growing attention in the literature on the performance of economies. For example, Chang et al. (2009) have shown that trade promotes growth when financial markets are better, the investment in human capital is stronger, labor market flexibility is higher, and firm entry is easier.

In the presence of distortions in more than one market, Lipsey and Lancaster (1956) pointed out that removing a distortion in a single market has an ambiguous effect on the welfare. Ensuring a favorable welfare effect requires elimination of distortions at once. Similarly, Foster and Sonnenschein (1970) showed that a proportional reduction in all distortions increases welfare. Rader (1976) generalized this result, making it less dependent on initial conditions.

These studies point out the importance of complimentary policy reforms to ensure a favorable welfare effect. However, these studies do not link complimentary policy reforms with corruption. Similarly, the literature on trade and corruption neglects the importance of complimentary policy reforms to fight against corruption. The present study fills the gap by introducing the importance of complimentary policy reforms in reducing corruption.

The literature on rent seeking, corruption, and trade shows the possibility of both positive and negative effects of trade on corruption. Most of the existing studies demonstrate a negative impact of trade on corruption. However, some of the recent studies have also begun to point out a possibility of the positive relationship between trade and corruption. The present study explores this relationship and empirically tests whether this relationship depends on domestic policy reforms and/or it is perhaps nonmonotonic. 


\section{Figure 1. Theory of corruption decreasing trade}

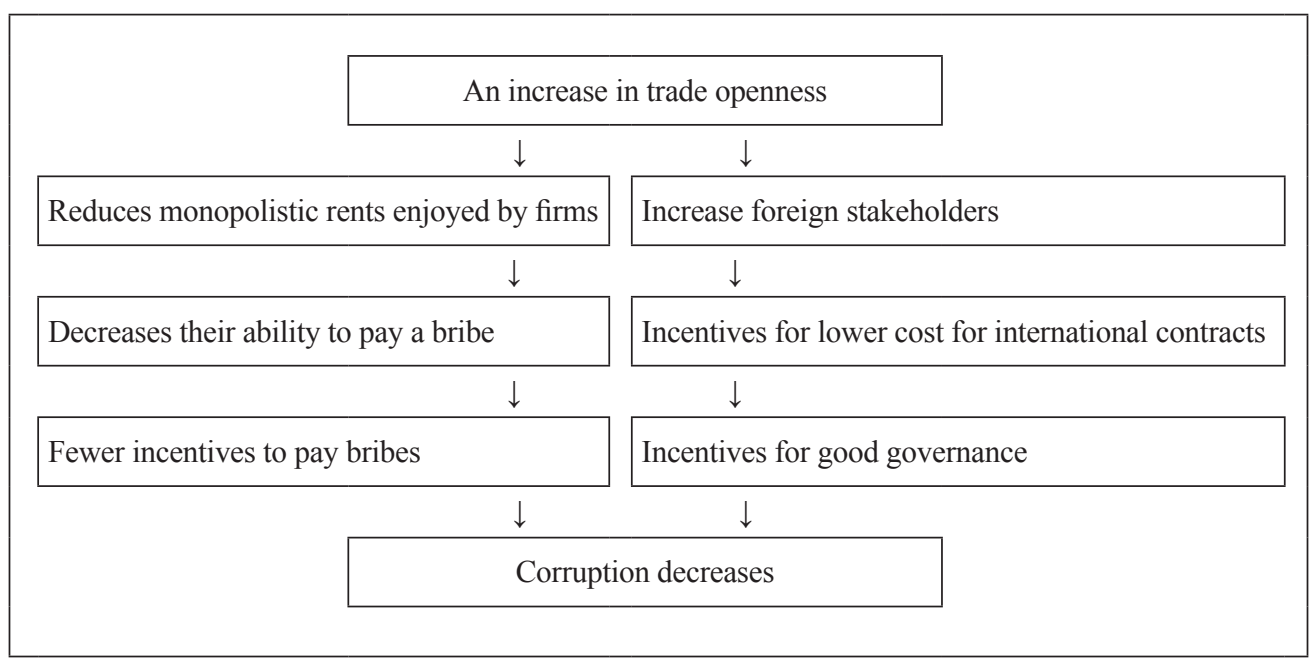

(Source) Krueger (1974), Ades and Di Tella (1999), Wei (1999), Gatti (2004)

Figure 2. Theory of corruption increasing trade

\begin{tabular}{|c|c|c|c|c|}
\hline & \multicolumn{3}{|c|}{ An increase in trade openness } & \\
\hline $\begin{array}{l}\text { Liberalization typically } \\
\text { increases imports }\end{array}$ & \multicolumn{2}{|l|}{$\begin{array}{l}\text { New opportunities of } \\
\text { corruption }\end{array}$} & $\begin{array}{l}\text { Integration of } \\
\text { county busine }\end{array}$ & $\begin{array}{l}\text { Monopolistic rents } \\
\text { decrease }\end{array}$ \\
\hline$\downarrow$ & \multicolumn{2}{|l|}{$\downarrow$} & $\downarrow$ & $\downarrow$ \\
\hline $\begin{array}{l}\text { Imports introduce new } \\
\text { goods and services }\end{array}$ & \multicolumn{2}{|c|}{$\begin{array}{l}\text { Obtaining foreign contract, } \\
\text { privileged access to markets, } \\
\text { specific gains such as tax } \\
\text { incentives and increase in trade } \\
\text { openness }\end{array}$} & $\begin{array}{l}\text { Cross country } \\
\text { business contr }\end{array}$ & $\begin{array}{l}\text { Value of monitoring of } \\
\text { bureaucracy decreases }\end{array}$ \\
\hline$\downarrow$ & \multicolumn{2}{|l|}{$\downarrow$} & $\downarrow$ & \\
\hline $\begin{array}{l}\text { Marginal utility of income } \\
\text { increases if consumers have } \\
\text { a desire for variety of goods }\end{array}$ & \multicolumn{2}{|c|}{$\begin{array}{l}\text { Mutual interests of } \\
\text { politicians and firms are } \\
\text { maximized }\end{array}$} & $\begin{array}{l}\text { corrupt behav } \\
\text { due to learnin } \\
\text { peer-group b }\end{array}$ & \\
\hline$\downarrow$ & \multicolumn{3}{|l|}{$\downarrow$} & $\downarrow$ \\
\hline $\begin{array}{l}\text { Marginal utility of bribe } \\
\text { income for custom official } \\
\text { increases }\end{array}$ & $\begin{array}{l}\text { Politicians need } \\
\text { money to finance } \\
\text { election campaigns }\end{array}$ & \multicolumn{2}{|c|}{$\begin{array}{l}\text { Firms need } \\
\text { business incentives }\end{array}$} & $\begin{array}{l}\text { Less check and } \\
\text { balances }\end{array}$ \\
\hline$\downarrow$ & $\downarrow$ & \multicolumn{2}{|l|}{$\downarrow$} & $\downarrow$ \\
\hline $\begin{array}{l}\text { Incentives for bribed } \\
\text { income increase }\end{array}$ & \multicolumn{4}{|c|}{ Corruption increases } \\
\hline
\end{tabular}




\section{Data Description}

Empirical studies on corruption mainly use two indexes of corruption provided by International Country Risk Guide (ICRG) and Transparency International (TI). In this study, corruption perception index by ICRG has been used for two reasons. (i) This index spans over a long time period. It also covers a large number of countries. Such a comprehensive nature of the index gives it an edge over other available indices for corruption. (ii) This index is highly correlated with other available corruption indices (Treisman 2000). This index has been widely used in the literature (Drabek Payne 2002, Pellegrini 2011, Elbahnasawy 2014)

Recently, Majeed and MacDonald (2010) show a correlation between these alternative corruption indices over the period 1984 2007. They show that correlation between ICRG and TI corruption indices is 0.87 while the correlation between ICRG and World Bank (WB)'s corruption indices is 0.88. Finally, their study shows a very high correlation, 0.98 , between TI and WB. These high correlations indicate that these alternative corruption indices are consistent even though they are based on subjective rating. The other variables used in this study are reported in Table A in the appendix. The data for this study has been averaged over 5-years non-over lapping period, 1984 2007. Thus, data series contain 5 observations for each country in the sample. The year average periods are: 1984 1988, 1989 1993, 1994 1998, 1999 2003, 2004 2007.

\section{Model and Estimation}

Theoretical formation of a model for this study relies on Becker (1968)'s seminal work where individuals make rational choices by giving weights to relative costs and benefits of an illegal (corrupt) activity. These costs and benefits depend on exogenous factors that, in turn, depend on the socio-cultural environment. The socio-cultural environment is developed by historical, legal, political, and country-specific factors. This study takes into account all these factors for an empirical analysis.

Trade openness increases competitiveness that, in turn, reduces rents and margins for corruption (Krueger 1974). Ades and Di Tella (1999) also provide similar line of 
research to show the corruption reducing effect of trade. However, they extend Krueger's argument by arguing corruption-increasing effect of trade. They argue that high trade barriers increase the value of monitoring of the bureaucracy, thereby reducing corruption. Conversely, trade liberalization causes more corruption.

Similarly, Treisman (2000) argues that corruption may actually rise if trade reform is not credible. Tanzi (1998) points out that trade creates new opportunities as bribes are obtain paid to foreign contracts or privileged markets access, or even specific benefits such as tax incentives. Following theoretical arguments and other empirical studies, corruption model is as follows:

$$
\begin{aligned}
& C_{i t}=\propto+\beta_{1} \text { Trade }_{i t}+\beta_{2} Y_{i t}+\beta_{3} X_{i t}+\mu_{i}+v_{t}+\varepsilon_{i t} \\
& \text { where }(i=1 \ldots \ldots \ldots \ldots \ldots N ; t=1 \ldots \ldots \ldots \ldots \ldots \ldots
\end{aligned}
$$

Where $C_{i t}$ is a perceived corruption index, Trade ${ }_{i t}$ represents openness to trade, $X_{i t}$ represents a set of control variables based on existing corruption literature, $\mu_{i}$ is a country specific unobservable effect, $v_{t}$ shows time specific factor and $\varepsilon_{i t}$ is an i.i.d. disturbance term. Expected sign for our key variable of interest are given as follows: $\beta_{1}>0 ; \beta_{2}<0$.

Equation (2) includes a non-liner term for openness to trade to test for non-linear relationship between trade and corruption. Expected signs for our key variables of interest are given as follows: $\beta_{1}>0 ; \beta_{2}<0$.

$$
C_{i t}=\propto+\beta_{1} \text { Trade }_{i t}+\beta_{2}\left(\text { Trade }^{2}{ }_{i t}+\beta_{3} Y_{i t}+\beta_{4} X_{i t}+\mu_{i}+v_{t}+\varepsilon_{i t}\right.
$$

Finally, Equation (3) includes an interactive term for trade and Domestic Conditions (DC) to test whether the effect of trade on corruption varies depending upon the domestic conditions of a trade integrating economy. In this study, two measures have been used for domestic conditions that are the quality of bureaucracy and financial development.

$$
C_{i t}=\propto+\beta_{1} \text { Trade }_{i t}+\beta_{2}\left(\text { Trade }^{2}{ }_{i t}+\beta_{3}\left(\text { Trade }_{i t} * D C_{i t}\right)+\beta_{4} Y_{i t}+\beta_{5} X_{i t}+\mu_{i}+v_{t}+\varepsilon_{i t}\right.
$$

\section{A. Estimation technique}

The use of pooled time-series and cross-section data provide large sample that is 
expected to yield efficient parameter estimates. Ordinary Least Squares (OLS) has a problem of omitted variable bias. If region, country or some group specific factors affect corruption, explanatory variables would capture the effects of these factors and estimates would not represent the true effect of explanatory variables. This analysis is based on 2SLS, LIML, and GMM techniques of estimation. These techniques address the issue of endogeniety that is covariance between independent variables and error term is not equal to zero and also address the problem of omitted variables bias. We also use alternative econometrics techniques such as random effects model and system GMM.

\section{Discussions}

Estimation strategy for this study is as follows: (i) Parameter estimates are obtained for trade which is a key variable. (ii) We estimate a non-monotonic relationship between trade and corruption. (iii) This study tests for interactive effects of trade on corruption to assess the importance of complimentary policy reforms. (iv) In order to control time factor, this study introduces five time dummies that are based on five year averages 1989 (1984 1989), 1994 (1990 1994), 1999 (1995 1999), 2004 (2000 2004) and 2007. (v) Alternative econometric techniques have been used to address the possible problem of endogeneity and to assess the robustness of results.

Table 1 shows the results for openness to trade and corruption. It is clear from all columns of Table 1 that trade significantly increases corruption. This result reveals that one standard deviation increase in trade leads to 0.025 unit increase in corruption. This finding is not consistent with the overwhelming consensus that trade reduces corruption. However, this finding helps to understand the question why corruption still exists or even rising despite growing trade liberalization. Thus, this finding supports the doubts on corruption reducing the role of trade. The impact of economic development on corruption is negative and significant, implying that countries at higher levels of economic development are likely to be less prone to corrupt activities. This finding is consistent with many studies in the literature (Pellegrini 2011, Elbahnasawy 2014, Tyburski 2014). In all specifications, higher law and order reduces corruption, at the $1 \%$ level of significance. This finding is consistent with Kim and Chang (2013). 
Table 1. Corruption and openness

(Panel Estimation)

\begin{tabular}{|c|c|c|c|c|c|c|c|}
\hline Variables & Dependen & t Variable: & Corruption & & & & \\
\hline $\begin{array}{l}\text { Trade } \\
\text { Openness }\end{array}$ & $\begin{array}{l}0.002 \\
(2.15)^{* *}\end{array}$ & $\begin{array}{l}0.002 \\
(2.43)^{*}\end{array}$ & $\begin{array}{l}0.003 \\
(3.68)^{*}\end{array}$ & $\begin{array}{l}0.004 \\
(4.39)^{*}\end{array}$ & $\begin{array}{l}0.003 \\
(3.36)^{*}\end{array}$ & $\begin{array}{l}0.002 \\
(2.82)^{*}\end{array}$ & $\begin{array}{l}0.004 \\
(4.08)^{*}\end{array}$ \\
\hline $\begin{array}{l}\text { Per Capita } \\
\text { Income }\end{array}$ & $\begin{array}{l}-0.000 \\
(-18.96)^{*}\end{array}$ & $\begin{array}{l}-0.000 \\
(-12.89)^{*}\end{array}$ & $\begin{array}{l}-0.000 \\
(-6.12)^{*}\end{array}$ & $\begin{array}{l}-0.000 \\
(-5.38)^{*}\end{array}$ & $\begin{array}{l}-0.000 \\
(-6.16)^{*}\end{array}$ & $\begin{array}{l}-0.000 \\
(-6.60)^{*}\end{array}$ & $\begin{array}{l}-0.000 \\
(-5.44)^{*}\end{array}$ \\
\hline $\begin{array}{l}\text { Economic } \\
\text { Freedom }\end{array}$ & & $\begin{array}{l}-0.21 \\
(-18.31)^{*}\end{array}$ & $\begin{array}{l}-0.16 \\
(-6.88)^{*}\end{array}$ & $\begin{array}{l}-0.17 \\
(-7.12)^{*}\end{array}$ & $\begin{array}{l}-0.07 \\
(-1.98)^{* *}\end{array}$ & - & $\begin{array}{l}-0.071 \\
(-2.07)^{* *}\end{array}$ \\
\hline $\begin{array}{l}\text { Rule of the } \\
\text { Law }\end{array}$ & & & $\begin{array}{l}-0.36 \\
(-10.11)^{*}\end{array}$ & $\begin{array}{l}-0.33 \\
(-9.17)^{*}\end{array}$ & $\begin{array}{l}-0.34 \\
(-8.99) *\end{array}$ & $\begin{array}{l}-0.29 \\
(-8.00)^{*}\end{array}$ & $\begin{array}{l}-0.29 \\
(-8.05)^{*}\end{array}$ \\
\hline $\begin{array}{l}\text { Government } \\
\text { Expenditure }\end{array}$ & & & & $\begin{array}{l}-0.034 \\
(-5.17)^{*}\end{array}$ & - & $\begin{array}{l}-0.028 \\
(-4.38)^{*}\end{array}$ & $\begin{array}{l}-0.034 \\
(-5.20)^{*}\end{array}$ \\
\hline Democracy & & & & & $\begin{array}{l}0.158 \\
(3.68)^{*}\end{array}$ & $\begin{array}{l}-0.21 \\
(-7.28)^{*}\end{array}$ & $\begin{array}{l}-0.16 \\
(-3.76)^{*}\end{array}$ \\
\hline $\mathrm{R}^{2}$ & 0.38 & 0.45 & 0.53 & 0.54 & 0.54 & 0.54 & 0.55 \\
\hline Adjusted $\mathrm{R}^{2}$ & 0.37 & 0.44 & 0.52 & 0.53 & 0.53 & 0.53 & 0.54 \\
\hline F-Test & $\begin{array}{l}183.31 \\
(0.000)\end{array}$ & $\begin{array}{l}158.40 \\
(0.000)\end{array}$ & $\begin{array}{l}164.48 \\
(0.000)\end{array}$ & $\begin{array}{l}137.46 \\
(0.000)\end{array}$ & $\begin{array}{l}137.06 \\
(0.000)\end{array}$ & $\begin{array}{l}138.42 \\
(0.000)\end{array}$ & $\begin{array}{l}119.47 \\
(0.000)\end{array}$ \\
\hline Observations & 608 & 600 & 600 & 591 & 600 & 598 & 591 \\
\hline
\end{tabular}

(Notes) (i) The $t$-statistics are given in parentheses.

(ii) * indicate significance at $1 \%$ level,

** indicate significance at $5 \%$ level,

*** indicate significance at $10 \%$ level.

Table 2 shows results that are obtained using random effects econometric technique. Now, parameter estimate for trade improves from 0.004 to 0.006 . In this case, one unit increase in standard deviation leads to 0.037 points increase in corruption. All other results remain same, however, coefficient on economic freedom slightly falls although it consistently remains significant. The other factors such as rule of law and government expenditures remain robustly significant with negative signs. 
Table 2. Corruption and openness

(Random effects)

\begin{tabular}{|c|c|c|c|c|c|c|c|}
\hline Variables & Depende & Variable: & orruptior & & & & \\
\hline $\begin{array}{l}\text { Trade } \\
\text { Openness }\end{array}$ & $\begin{array}{l}0.006 \\
(4.47)^{* *}\end{array}$ & $\begin{array}{l}0.006 \\
(4.60)^{*}\end{array}$ & $\begin{array}{l}0.006 \\
(5.15)^{*}\end{array}$ & $\begin{array}{l}0.006 \\
(5.46)^{*}\end{array}$ & $\begin{array}{l}-0.006 \\
(-4.70)^{*}\end{array}$ & $\begin{array}{l}0.005 \\
(4.63)^{*}\end{array}$ & $\begin{array}{l}0.006 \\
(5.32)^{*}\end{array}$ \\
\hline $\begin{array}{l}\text { Per Capita } \\
\text { Income }\end{array}$ & $\begin{array}{l}-0.000 \\
(-7.78)^{*}\end{array}$ & $\begin{array}{l}-0.000 \\
(-7.40)^{*}\end{array}$ & $\begin{array}{l}-0.000 \\
(-4.71)^{*}\end{array}$ & $\begin{array}{l}-0.000 \\
(-3.65)^{*}\end{array}$ & $\begin{array}{l}-0.000 \\
(-6.53)^{*}\end{array}$ & $\begin{array}{l}-0.000 \\
(-4.63)^{*}\end{array}$ & $\begin{array}{l}-0.000 \\
(-3.82)^{*}\end{array}$ \\
\hline $\begin{array}{l}\text { Economic } \\
\text { Freedom }\end{array}$ & & $\begin{array}{l}-0.12 \\
(-3.80)^{*}\end{array}$ & $\begin{array}{l}-0.09 \\
(-2.95)^{*}\end{array}$ & $\begin{array}{l}-0.095 \\
(-3.18)^{*}\end{array}$ & $\begin{array}{l}-0.064 \\
(-1.63)^{* *}\end{array}$ & & $\begin{array}{l}-0.07 \\
(-1.89)^{* *}\end{array}$ \\
\hline $\begin{array}{l}\text { Rule of the } \\
\text { Law }\end{array}$ & & & $\begin{array}{l}-0.29 \\
(-7.62)^{*}\end{array}$ & $\begin{array}{l}-0.28 \\
(-7.57)^{*}\end{array}$ & & $\begin{array}{l}-0.27 \\
(-7.08)^{*}\end{array}$ & $\begin{array}{l}-0.27 \\
(-7.06)^{*}\end{array}$ \\
\hline $\begin{array}{l}\text { Government } \\
\text { Expenditure }\end{array}$ & & & & $\begin{array}{l}-0.045 \\
(-5.43)^{*}\end{array}$ & $\begin{array}{l}-0.05 \\
(-5.39)^{*}\end{array}$ & $\begin{array}{l}-0.04 \\
(-4.95)^{*}\end{array}$ & $\begin{array}{l}-0.04 \\
(-5.45)\end{array}$ \\
\hline Democracy & & & & & $\begin{array}{l}-0.13 \\
(-2.97)^{*}\end{array}$ & $\begin{array}{l}-0.09 \\
(-2.76)^{*}\end{array}$ & $\begin{array}{l}-0.053 \\
(-1.26)^{*}\end{array}$ \\
\hline Between $\mathrm{R}^{2}$ & 0.40 & 0.53 & 0.62 & 0.61 & 0.60 & 0.62 & 0.63 \\
\hline Overall $\mathrm{R}^{2}$ & 0.33 & 0.41 & 0.50 & 0.51 & 0.48 & 0.51 & 0.52 \\
\hline Observations & 608 & 600 & 600 & 591 & 591 & 598 & 591 \\
\hline
\end{tabular}

(Notes) (i) The $t$-statistics are given in parentheses.

(ii) $*$ indicate significance at $1 \%$ level,

** indicate significance at 5\% level,

*** indicate significance at $10 \%$ level.

Table 3 shows results based on a comprehensive sensitivity analysis using 13 additional causes of corruption. The coefficient on openness remains robustly significant with positive sign and coefficient fluctuate between 0.003 and 0.004 . The most significant factors observed in this sensitivity analysis are bureaucracy quality, government stability, and investment profile while arms trade and external conflict turn out to be the least significant determinants of corruption. 
Table 3. Corruption and openness

(Sensitivity Analysis 1)

\begin{tabular}{|c|c|c|c|c|c|c|c|c|}
\hline Variables & Depende & nt Variab & e: Corrup & tion & & & & \\
\hline \begin{tabular}{|l} 
Trade \\
Openness
\end{tabular} & $\begin{array}{l}0.003 \\
(3.68)^{*}\end{array}$ & $\begin{array}{l}0.004 \\
(4.28)^{*}\end{array}$ & $\begin{array}{l}0.002 \\
(2.44)^{*}\end{array}$ & $\begin{array}{l}0.003 \\
(3.14)^{*}\end{array}$ & $\begin{array}{l}0.003 \\
(3.52)^{*}\end{array}$ & $\begin{array}{l}0.002 \\
(1.77)^{* * *}\end{array}$ & \begin{tabular}{|l}
0.004 \\
$(4.36)^{*}$
\end{tabular} & $\begin{array}{l}0.012 \\
(7.39)^{*}\end{array}$ \\
\hline $\begin{array}{l}\text { Per Capita } \\
\text { Income }\end{array}$ & $\begin{array}{l}-0.000 \\
(-6.12)^{*}\end{array}$ & $\begin{array}{l}-0.000 \\
-6.26)^{*}\end{array}$ & $\begin{array}{l}-0.000 \\
(-6.18)^{*}\end{array}$ & $\begin{array}{l}-0.000 \\
(-5.82)^{*}\end{array}$ & $\begin{array}{l}-0.000 \\
(-5.92)^{*}\end{array}$ & $\begin{array}{l}-0.000 \\
(-7.70)^{*}\end{array}$ & $\begin{array}{l}-0.000 \\
(-5.78)^{*}\end{array}$ & $\begin{array}{l}-0.000 \\
(-3.36)^{*}\end{array}$ \\
\hline $\begin{array}{l}\text { Economic } \\
\text { Freedom }\end{array}$ & $\begin{array}{l}-0.16 \\
(-6.88)^{*}\end{array}$ & $\begin{array}{l}-0.16 \\
(-6.73)^{*}\end{array}$ & $\begin{array}{l}-0.15 \\
(-6.42)^{*}\end{array}$ & $\begin{array}{l}-0.18 \\
(-7.1)^{*}\end{array}$ & $\begin{array}{l}-0.17 \\
(-6.80)^{*}\end{array}$ & $\begin{array}{l}-0.20 \\
(-8.75)^{*}\end{array}$ & $\begin{array}{l}-0.12 \\
(-4.89)^{*}\end{array}$ & $\begin{array}{l}-0.14 \\
(-6.01)^{*}\end{array}$ \\
\hline $\begin{array}{l}\text { Rule of the } \\
\text { Law }\end{array}$ & $\begin{array}{l}-0.36 \\
(-10.11)^{*}\end{array}$ & $\begin{array}{l}-0.36 \\
(-10.36)^{*}\end{array}$ & $\begin{array}{l}-0.43 \\
(-11.7)^{*}\end{array}$ & $\begin{array}{l}-0.41 \\
(-8.98)^{*}\end{array}$ & $\begin{array}{l}-0.37 \\
(-9.83)^{*}\end{array}$ & $\begin{array}{l}-0.41 \\
(-11.85)^{*}\end{array}$ & $\begin{array}{l}-0.30 \\
(-7.69)^{*}\end{array}$ & $\begin{array}{l}-0.31 \\
(-8.87)^{*}\end{array}$ \\
\hline Urbanization & & $\begin{array}{l}0.000 \\
(2.65)^{*}\end{array}$ & & & & & & \\
\hline $\begin{array}{l}\text { Government } \\
\text { Stability }\end{array}$ & & & $\begin{array}{l}0.121 \\
(5.66)^{*}\end{array}$ & & & & & \\
\hline $\begin{array}{l}\text { Internal } \\
\text { Conflict }\end{array}$ & & & & $\begin{array}{l}0.05 \\
(1.87)^{* * *}\end{array}$ & & & & \\
\hline $\begin{array}{l}\text { External } \\
\text { Conflict }\end{array}$ & & & & & $\begin{array}{l}0.021 \\
(0.93)\end{array}$ & & & \\
\hline $\begin{array}{l}\text { Investment } \\
\text { Profile }\end{array}$ & & & & & & $\begin{array}{l}0.15 \\
(7.49)^{*}\end{array}$ & & \\
\hline \begin{tabular}{|l|} 
Military \\
Politics
\end{tabular} & & & & & & & $\begin{array}{l}-0.12 \\
(-3.57)^{*}\end{array}$ & \\
\hline $\begin{array}{l}\text { Openness* } \\
\text { Bureaucracy } \\
\text { Quality } \\
\end{array}$ & & & & & & & & $\begin{array}{l}-0.003 \\
(-6.35)^{*}\end{array}$ \\
\hline $\mathrm{R}^{2}$ & 0.53 & 0.53 & 0.55 & 0.53 & 0.53 & 0.57 & 0.54 & 0.56 \\
\hline Adjusted $\mathrm{R}^{2}$ & 0.52 & 0.53 & 0.54 & 0.52 & 0.52 & 0.56 & 0.53 & 0.55 \\
\hline F-Test & $\begin{array}{l}164.48 \\
(0.000)\end{array}$ & $\begin{array}{l}134.33 \\
(0.000)\end{array}$ & $\begin{array}{l}144.84 \\
(0.000)\end{array}$ & $\begin{array}{l}132.84 \\
(0.000)\end{array}$ & $\begin{array}{l}131.73 \\
(0.000)\end{array}$ & $\begin{array}{l}154.96 \\
(0.000)\end{array}$ & $\begin{array}{l}136.73 \\
(0.000)\end{array}$ & $\begin{array}{l}148.33 \\
(0.000)\end{array}$ \\
\hline Observations & 600 & 600 & 600 & 600 & 600 & 600 & 600 & 600 \\
\hline
\end{tabular}

(Notes) (i) The $t$-statistics are given in parentheses.

(ii) * indicate significance at $1 \%$ level,

$* *$ indicate significance at $5 \%$ level,

*** indicate significance at $10 \%$ level.

Tables $6 \sim 8$ shows results with a nonlinear term for trade openness. It is evident from all regressions that the corruption increasing effect in a liner term turns out to be corruption decreasing effect in a nonlinear term. Thus, corruption increases at lower levels of trade 
openness and decreases at higher levels of trade openness.

Earlier studies on trade-corruption relationship ignore the role of complimentary policy reforms. This study argues that this is not just trade openness but other complementary factors such as rule of law, financial reforms, bureaucracy quality among others also matter in transmitting the favorable effects of openness on corruption. In order to assess this proposition, this study includes an interactive term of openness and bureaucracy quality and finds highly significant negative effect on corruption as shown in Table 3. Thus, this is not just trade openness but also complementary reforms matter in reducing corruption. Similarly, domestic financial development also plays a complimentary role to reduce the corruption. The independent effect of trade is corruption increasing while combined effect of financial development and trade is corruption decreasing as shown in Table 6. 
Table 4. Corruption and openness

(Sensitivity Analysis 2)

\begin{tabular}{|c|c|c|c|c|c|c|c|}
\hline Variables & Dependen & Variable: & orruption & & & & \\
\hline $\begin{array}{l}\text { Trade } \\
\text { Openness }\end{array}$ & $\begin{array}{l}0.003 \\
(3.68)^{*}\end{array}$ & $\begin{array}{l}0.003 \\
(3.74)^{*}\end{array}$ & $\begin{array}{l}0.003 \\
(4.11)^{*}\end{array}$ & $\begin{array}{l}0.003 \\
(1.81)^{* * *}\end{array}$ & $\begin{array}{l}0.003 \\
(3.29)^{*}\end{array}$ & $\begin{array}{l}0.003 \\
(3.50)^{*}\end{array}$ & $\begin{array}{l}0.003 \\
(3.26)^{*}\end{array}$ \\
\hline $\begin{array}{l}\text { Per Capita } \\
\text { Income }\end{array}$ & $\begin{array}{l}-0.000 \\
(-6.12)^{*}\end{array}$ & $\begin{array}{l}-0.000 \\
(-6.23)^{*}\end{array}$ & $\begin{array}{l}-0.000 \\
(-2.91)^{*}\end{array}$ & $\begin{array}{l}-0.000 \\
(-3.55)^{*}\end{array}$ & $\begin{array}{l}-0.000 \\
(-6.50)^{*}\end{array}$ & $\begin{array}{l}-0.000 \\
(-5.11)^{*}\end{array}$ & $\begin{array}{l}-0.000 \\
(-6.73)^{*}\end{array}$ \\
\hline $\begin{array}{l}\text { Economic } \\
\text { Freedom }\end{array}$ & $\begin{array}{l}-0.16 \\
(-6.88)^{*}\end{array}$ & $\begin{array}{l}-0.14 \\
(-5.63)^{*}\end{array}$ & $\begin{array}{l}-0.10 \\
(-4.34)^{*}\end{array}$ & $\begin{array}{l}-0.19 \\
(-4.91)^{*}\end{array}$ & $\begin{array}{l}-0.16 \\
(-6.64)^{*}\end{array}$ & $\begin{array}{l}-0.17 \\
(-7.00)^{*}\end{array}$ & $\begin{array}{l}-0.13 \\
(-4.90)^{*}\end{array}$ \\
\hline $\begin{array}{l}\text { Rule of the } \\
\text { Law }\end{array}$ & $\begin{array}{l}-0.36 \\
(-10.11)^{*}\end{array}$ & $\begin{array}{l}-0.34 \\
(-9.62)^{*}\end{array}$ & $\begin{array}{l}-0.25 \\
(-6.86)^{*}\end{array}$ & $\begin{array}{l}-0.43 \\
(-6.59)^{*}\end{array}$ & $\begin{array}{l}-0.36 \\
(-10.09)^{*}\end{array}$ & $\begin{array}{l}-0.32 \\
(-8.87)^{*}\end{array}$ & $\begin{array}{l}-0.35 \\
(-9.68)^{*}\end{array}$ \\
\hline $\begin{array}{l}\text { Religion in } \\
\text { Politics }\end{array}$ & & $\begin{array}{l}0.08 \\
(2.34)^{*}\end{array}$ & & & & & \\
\hline $\begin{array}{l}\text { Bureaucracy } \\
\text { Quality }\end{array}$ & & & $\begin{array}{l}0.399 \\
(7.77)^{*}\end{array}$ & & & & \\
\hline Arm Trade & & & & $\begin{array}{l}0.000 \\
(1.55)\end{array}$ & & & \\
\hline Inflation & & & & & $\begin{array}{l}0.000 \\
(2.11)^{*}\end{array}$ & & \\
\hline$H F I$ & & & & & & $\begin{array}{l}0.000 \\
(1.90)^{*}\end{array}$ & \\
\hline Remittances & & & & & & & $\begin{array}{l}0.013 \\
(1.6)^{* * *}\end{array}$ \\
\hline $\mathrm{R}^{2}$ & 0.53 & 0.53 & 0.57 & 0.58 & 0.56 & 0.47 & 0.58 \\
\hline Adjusted $\mathrm{R}^{2}$ & 0.52 & 0.53 & 0.56 & 0.57 & 0.55 & 0.46 & 0.57 \\
\hline F-Test & $\begin{array}{l}164.48 \\
(0.000)\end{array}$ & $\begin{array}{l}134.08 \\
(0.000)\end{array}$ & $\begin{array}{l}156.80 \\
(0.000)\end{array}$ & $\begin{array}{l}63.32 \\
(0.000)\end{array}$ & $\begin{array}{l}141.96 \\
(0.000)\end{array}$ & $\begin{array}{l}90.10 \\
(0.000)\end{array}$ & $\begin{array}{l}133.33 \\
(0.000)\end{array}$ \\
\hline Observations & 600 & 600 & 600 & 600 & 600 & 600 & 600 \\
\hline
\end{tabular}

(Notes) (i) The $t$-statistics are given in parentheses.

(ii) $*$ indicate significance at $1 \%$ level,

** indicate significance at $5 \%$ level,

*** indicate significance at $10 \%$ level. 
Table 5. Corruption and openness

(Panel Estimation (IVE))

\begin{tabular}{|c|c|c|c|c|c|c|}
\hline Variables & IV & LIML & GMM & IV & LIML & GMM \\
\hline $\begin{array}{l}\text { Trade } \\
\text { Openness }\end{array}$ & $\begin{array}{l}0.002 \\
(2.53)^{*}\end{array}$ & $\begin{array}{l}0.003 \\
(2.53)^{*}\end{array}$ & $\begin{array}{l}0.003 \\
(2.94)^{*}\end{array}$ & $\begin{array}{l}0.002 \\
(2.32)^{* *}\end{array}$ & $\begin{array}{l}0.002 \\
(2.32)^{* *}\end{array}$ & $\begin{array}{l}0.003 \\
(2.92)^{*}\end{array}$ \\
\hline $\begin{array}{l}\text { Per Capita } \\
\text { Income }\end{array}$ & $\begin{array}{l}-0.000 \\
(-6.31)^{*}\end{array}$ & $\begin{array}{l}-0.000 \\
(-6.31)^{*}\end{array}$ & $\begin{array}{l}-0.000 \\
(-6.19)^{*}\end{array}$ & $\begin{array}{l}-0.000 \\
(-5.91)^{*}\end{array}$ & $\begin{array}{l}-0.000 \\
(-5.90)^{*}\end{array}$ & $\begin{array}{l}-0.000 \\
(-5.95)^{*}\end{array}$ \\
\hline Democracy & $\begin{array}{l}-0.08 \\
(-1.53)\end{array}$ & $\begin{array}{l}-0.08 \\
(-1.53)\end{array}$ & $\begin{array}{l}-0.08 \\
(-1.63)^{* * *}\end{array}$ & $\begin{array}{l}-0.11 \\
(-1.98)^{* *}\end{array}$ & $\begin{array}{l}-0.11 \\
(-1.98) * *\end{array}$ & $\begin{array}{l}-0.11 \\
(-2.11)^{* *}\end{array}$ \\
\hline $\begin{array}{l}\text { Bureaucracy } \\
\text { Quality }\end{array}$ & $\begin{array}{l}-0.32 \\
(-3.94)^{*}\end{array}$ & $\begin{array}{l}-0.32 \\
(-3.99) *\end{array}$ & $\begin{array}{l}-0.33 \\
(-4.72)^{*}\end{array}$ & $\begin{array}{l}-0.31 \\
(-3.69)^{*}\end{array}$ & $\begin{array}{l}-0.31 \\
(-3.67)^{*}\end{array}$ & $\begin{array}{l}-0.30 \\
(-4.10)^{*}\end{array}$ \\
\hline $\begin{array}{l}\text { Government } \\
\text { Spending }\end{array}$ & $\begin{array}{l}-0.04 \\
(-3.45)^{*}\end{array}$ & $\begin{array}{l}-0.04 \\
(-3.45)^{*}\end{array}$ & $\begin{array}{l}-0.04 \\
(-3.46)^{*}\end{array}$ & $\begin{array}{l}-0.04 \\
(-3.28)^{*}\end{array}$ & $\begin{array}{l}-0.03 \\
(-3.29)^{*}\end{array}$ & $\begin{array}{l}-0.04 \\
(-3.63)^{*}\end{array}$ \\
\hline Remittances & - & - & - & $\begin{array}{l}0.02 \\
(1.76)^{* * *}\end{array}$ & $\begin{array}{l}0.02 \\
(1.76)^{* * *}\end{array}$ & $\begin{array}{l}0.01 \\
(1.5)\end{array}$ \\
\hline $\mathrm{R}^{2}$ & 0.58 & 0.58 & 0.58 & 0.58 & 0.58 & 0.59 \\
\hline Sargan-Test & $\begin{array}{l}2.03 \\
\mathrm{P}=0.36\end{array}$ & $\begin{array}{l}2.03 \\
\mathrm{P}=0.36\end{array}$ & $\begin{array}{l}2.39 \\
\mathrm{P}=0.29\end{array}$ & $\begin{array}{l}2.94 \\
\mathrm{P}=0.23\end{array}$ & $\begin{array}{l}2.97 \\
\mathrm{P}=0.23\end{array}$ & \\
\hline Basmann-Test & $\begin{array}{l}2.0 \\
\mathrm{P}=0.37\end{array}$ & $\begin{array}{l}1.00 \\
\mathrm{P}=0.37\end{array}$ & & $\begin{array}{l}2.90 \\
\mathrm{P}=0.24\end{array}$ & $\begin{array}{l}1.45 \\
\mathrm{P}=0.24\end{array}$ & \\
\hline Observations & 380 & 380 & 380 & 376 & 376 & 376 \\
\hline
\end{tabular}

(Notes) (i) The $t$-statistics are given in parentheses.

(ii) $*$ indicate significance at $1 \%$ level,

** indicate significance at 5\% level,

*** indicate significance at $10 \%$ level. 
Table 6. Corruption and openness

(Nonlinearity)

\begin{tabular}{|c|c|c|c|c|c|c|c|}
\hline Variable & Depen & t Variabl & Corrupt & & & & \\
\hline $\begin{array}{l}\text { Trade } \\
\text { Openness }\end{array}$ & $\begin{array}{l}0.007 \\
(3.72)^{* *}\end{array}$ & $\begin{array}{l}0.012 \\
(5.35)^{*}\end{array}$ & $\begin{array}{l}0.011 \\
(5.41)^{*}\end{array}$ & $\begin{array}{l}0.009 \\
(4.23)^{*}\end{array}$ & $\begin{array}{l}0.009 \\
(4.95)^{*}\end{array}$ & $\begin{array}{l}0.007 \\
(3.74)^{*}\end{array}$ & $\begin{array}{l}0.01 \\
(5.93)^{*}\end{array}$ \\
\hline Trade $^{2}$ & $\begin{array}{l}-0.000 \\
(-2.33)^{*}\end{array}$ & $\begin{array}{l}-0.000 \\
(-3.83)^{*}\end{array}$ & $\begin{array}{l}-0.000 \\
(-4.04)^{*}\end{array}$ & $\begin{array}{l}-0.000 \\
(-3.18)^{*}\end{array}$ & $\begin{array}{l}-0.000 \\
(-4.15)^{*}\end{array}$ & $\begin{array}{l}-0.000 \\
(-2.50)^{*}\end{array}$ & $\begin{array}{l}-0.000 \\
(-3.18)^{*}\end{array}$ \\
\hline $\begin{array}{l}\text { Per Capita } \\
\text { Income }\end{array}$ & $\begin{array}{l}-0.000 \\
(-5.54)^{*}\end{array}$ & $\begin{array}{l}-0.000 \\
(-4.34)^{*}\end{array}$ & $\begin{array}{l}-0.000 \\
(-4.36)^{*}\end{array}$ & $\begin{array}{l}-0.000 \\
(-9.35)^{*}\end{array}$ & $\begin{array}{l}-0.000 \\
(-5.35)^{*}\end{array}$ & $\begin{array}{l}-0.000 \\
(-5.55)^{*}\end{array}$ & $\begin{array}{l}-0.000 \\
(-3.22)^{*}\end{array}$ \\
\hline $\begin{array}{l}\text { Economic } \\
\text { Freedom }\end{array}$ & $\begin{array}{l}-0.17 \\
(-7.14)^{*}\end{array}$ & $\begin{array}{l}-0.18 \\
(-7.67) *\end{array}$ & $\begin{array}{l}-0.08 \\
(-2.35)^{*}\end{array}$ & $\begin{array}{l}-0.06 \\
(-1.71)^{* * *}\end{array}$ & - & $\begin{array}{l}-0.07 \\
(-2.12)^{*}\end{array}$ & $\begin{array}{l}-0.19 \\
(-7.78)^{*}\end{array}$ \\
\hline $\begin{array}{l}\text { Rule of the } \\
\text { Law }\end{array}$ & $\begin{array}{l}-0.37 \\
(-10.36)^{*}\end{array}$ & $\begin{array}{l}-0.34 \\
(-9.60)^{*}\end{array}$ & $\begin{array}{l}-0.30 \\
(-8.45)^{*}\end{array}$ & - & $\begin{array}{l}-0.30 \\
(-8.42)\end{array}$ & $\begin{array}{l}-0.34 \\
(-9.26)\end{array}$ & $\begin{array}{l}-0.31 \\
(-8.40)^{*}\end{array}$ \\
\hline $\begin{array}{l}\text { Government } \\
\text { expenditure }\end{array}$ & & $\begin{array}{l}-0.04 \\
-(6.05)^{*}\end{array}$ & $\begin{array}{l}-0.04 \\
-(6.14)^{*}\end{array}$ & $\begin{array}{l}-0.05 \\
-(6.83)^{*}\end{array}$ & $\begin{array}{l}-0.04 \\
-(5.46)^{*}\end{array}$ & - & $\begin{array}{l}-0.04 \\
(-5.26)^{*}\end{array}$ \\
\hline Democracy & - & - & $\begin{array}{l}-0.17 \\
(-3.97) *\end{array}$ & $\begin{array}{l}-0.25 \\
(-5.88)^{*}\end{array}$ & $\begin{array}{l}-0.23 \\
(-7.93)^{*}\end{array}$ & $\begin{array}{l}-0.16 \\
(-3.79)^{*}\end{array}$ & - \\
\hline Trade*HFI & & & & & & & $\begin{array}{l}-0.000 \\
(-2.56)^{*}\end{array}$ \\
\hline $\mathrm{R}^{2}$ & 0.53 & 0.55 & 0.57 & 0.51 & 0.55 & 0.55 & 0.50 \\
\hline Adjusted $\mathrm{R}^{2}$ & 0.52 & 0.54 & 0.56 & 0.50 & 0.54 & 0.54 & 0.49 \\
\hline F-Test & $\begin{array}{l}133.65 \\
(0.000)\end{array}$ & $\begin{array}{l}119.66 \\
(0.000)\end{array}$ & $\begin{array}{l}107.41 \\
(0.000)\end{array}$ & $\begin{array}{l}101.11 \\
(0.000)\end{array}$ & $\begin{array}{l}121.38 \\
(0.000)\end{array}$ & $\begin{array}{l}116.27 \\
(0.000)\end{array}$ & $\begin{array}{l}71.84 \\
(0.000)\end{array}$ \\
\hline Observations & 600 & 600 & 591 & 591 & 591 & 591 & 591 \\
\hline
\end{tabular}

(Notes) (i) The $t$-statistics are given in parentheses.

(ii) * indicate significance at $1 \%$ level,

$* *$ indicate significance at $5 \%$ level,

*** indicate significance at 10\% level. 
Table 7. Corruption and openness

(Random Effects)

\begin{tabular}{|c|c|c|c|c|c|c|c|}
\hline Variables & Depende & t Variabl & Corrupt & & & & \\
\hline $\begin{array}{l}\text { Trade } \\
\text { Openness }\end{array}$ & $\begin{array}{l}0.014 \\
(5.55)^{*}\end{array}$ & $\begin{array}{l}0.017 \\
(6.81)^{*}\end{array}$ & $\begin{array}{l}0.012 \\
(6.85)^{*}\end{array}$ & $\begin{array}{l}0.014 \\
(5.43)^{*}\end{array}$ & $\begin{array}{l}0.018 \\
(7.22)^{*}\end{array}$ & $\begin{array}{l}0.011 \\
(4.39)^{*}\end{array}$ & $\begin{array}{l}0.017 \\
(6.70)^{*}\end{array}$ \\
\hline Trade ${ }^{2}$ & $\begin{array}{l}-0.000 \\
(-3.54)^{*}\end{array}$ & $\begin{array}{l}-0.000 \\
(-4.84)^{*}\end{array}$ & $\begin{array}{l}-0.000 \\
(-4.96)^{*}\end{array}$ & $\begin{array}{l}-0.000 \\
(-4.03)^{*}\end{array}$ & $\begin{array}{l}-0.000 \\
(-5.03)^{*}\end{array}$ & $\begin{array}{l}-0.000 \\
(-3.37)^{*}\end{array}$ & $\begin{array}{l}-0.000 \\
(-4.57)^{*}\end{array}$ \\
\hline $\begin{array}{l}\text { Per Capita } \\
\text { Income }\end{array}$ & $\begin{array}{l}-0.000 \\
(-3.92)^{*}\end{array}$ & $\begin{array}{l}-0.000 \\
(-2.52)^{*}\end{array}$ & $\begin{array}{l}-0.000 \\
(-2.65)^{*}\end{array}$ & $\begin{array}{l}-0.000 \\
(-2.58)^{*}\end{array}$ & $\begin{array}{l}-0.000 \\
(-2.03)^{* *}\end{array}$ & $\begin{array}{l}-0.000 \\
(-4.73)^{*}\end{array}$ & $\begin{array}{l}-0.000 \\
(-2.27)^{* *}\end{array}$ \\
\hline $\begin{array}{l}\text { Economic } \\
\text { Freedom }\end{array}$ & $\begin{array}{l}0.11 \\
(3.46)^{*}\end{array}$ & $\begin{array}{l}0.12 \\
(4.01)^{*}\end{array}$ & $\begin{array}{l}0.04 \\
(2.29)^{*}\end{array}$ & $\begin{array}{l}0.12 \\
(4.07)^{*}\end{array}$ & $\begin{array}{l}0.076 \\
(2.46)^{*}\end{array}$ & $\begin{array}{l}0.16 \\
(5.66)^{*}\end{array}$ & $\begin{array}{l}0.13 \\
(4.21)^{*}\end{array}$ \\
\hline $\begin{array}{l}\text { Rule of the } \\
\text { Law }\end{array}$ & $\begin{array}{l}-0.30 \\
(-8.03)^{*}\end{array}$ & $\begin{array}{l}-0.30 \\
(-8.19)^{*}\end{array}$ & $\begin{array}{l}-0.29 \\
(-7.57) *\end{array}$ & $\begin{array}{l}-0.37 \\
(-9.58) *\end{array}$ & $\begin{array}{l}-0.24 \\
(-6.22)^{*}\end{array}$ & $\begin{array}{l}-0.33 \\
(-9.45)\end{array}$ & $\begin{array}{l}-0.27 \\
(-7.12) *\end{array}$ \\
\hline $\begin{array}{l}\text { Government } \\
\text { expenditure }\end{array}$ & - & $\begin{array}{l}-0.05 \\
-(6.39)^{*}\end{array}$ & $\begin{array}{l}-0.05 \\
-(6.46)^{*}\end{array}$ & $\begin{array}{l}-0.05 \\
-(5.34)^{*}\end{array}$ & $\begin{array}{l}-0.049 \\
-(5.94) *\end{array}$ & $\begin{array}{l}-0.04 \\
(-4.99)\end{array}$ & $\begin{array}{l}-0.05 \\
(-5.46) *\end{array}$ \\
\hline Democracy & - & - & $\begin{array}{l}-0.07 \\
(-1.75)^{*}\end{array}$ & & & & - \\
\hline $\begin{array}{l}\text { Government } \\
\text { Stability }\end{array}$ & & & & $\begin{array}{l}0.094 \\
(5.08)^{*}\end{array}$ & & & $\begin{array}{l}-0.000 \\
(-2.56)^{*}\end{array}$ \\
\hline $\begin{array}{l}\text { Military in } \\
\text { Politics }\end{array}$ & & & & & $\begin{array}{l}-0.15 \\
(-4.04)^{*}\end{array}$ & & \\
\hline $\begin{array}{l}\text { Investment } \\
\text { Profiles }\end{array}$ & & & & & & $\begin{array}{l}0.15 \\
(8.38)^{*}\end{array}$ & \\
\hline Trade*HFI & & & & & & & $\begin{array}{l}-0.000 \\
(-1.00)\end{array}$ \\
\hline Overall $\mathrm{R}^{2}$ & 0.63 & 0.65 & 0.67 & 0.67 & 0.64 & 0.68 & 0.60 \\
\hline Between $\mathrm{R}^{2}$ & 0.50 & 0.52 & 0.53 & 0.54 & 0.53 & 0.57 & 0.47 \\
\hline Observations & 600 & 591 & 591 & 591 & 591 & 591 & 591 \\
\hline
\end{tabular}

(Notes) (i) The $t$-statistics are given in parentheses.

(ii) $*$ indicate significance at $1 \%$ level,

$* *$ indicate significance at $5 \%$ level,

*** indicate significance at $10 \%$ level. 
Table 8. Corruption and openness

(Nonlinearity: Sensitivity Analysis)

\begin{tabular}{|c|c|c|c|c|c|c|c|c|}
\hline \multirow{2}{*}{\begin{tabular}{|l|} 
Variables \\
Trade \\
Openness
\end{tabular}} & \multicolumn{8}{|c|}{ Dependent Variable: Corruption } \\
\hline & $\begin{array}{l}0.012 \\
(5.35)^{*}\end{array}$ & $\begin{array}{l}0.009 \\
(4.48)^{*}\end{array}$ & $\begin{array}{l}0.007 \\
(3.90)^{*}\end{array}$ & $\begin{array}{l}0.011 \\
(5.67)^{*}\end{array}$ & $\begin{array}{l}0.009 \\
(5.08)^{*}\end{array}$ & $\begin{array}{l}0.013 \\
(5.08)^{*}\end{array}$ & $\begin{array}{l}0.012 \\
(5.57)^{*}\end{array}$ & $\begin{array}{l}0.006 \\
(3.15)^{*}\end{array}$ \\
\hline Trade ${ }^{2}$ & $\begin{array}{l}-0.000 \\
(-3.83)^{*}\end{array}$ & $\begin{array}{l}-0.000 \\
(-3.42)^{*}\end{array}$ & $\begin{array}{l}-0.000 \\
(-3.14)^{*}\end{array}$ & $\begin{array}{l}-0.000 \\
(-3.96)^{*}\end{array}$ & $\begin{array}{l}-0.000 \\
(-3.42)^{*}\end{array}$ & $\begin{array}{l}-0.000 \\
(-4.24)^{*}\end{array}$ & $\begin{array}{l}-0.000 \\
(-4.07)^{*}\end{array}$ & $\begin{array}{l}-0.000 \\
(-2.65)^{*}\end{array}$ \\
\hline $\begin{array}{l}\text { Per Capita } \\
\text { Income }\end{array}$ & $\begin{array}{l}-0.000 \\
(-4.34)^{*}\end{array}$ & $\begin{array}{l}-0.000 \\
(-4.57)^{*}\end{array}$ & $\begin{array}{l}-0.000 \\
(-5.97)^{*}\end{array}$ & $\begin{array}{l}-0.000 \\
(-4.11)^{*}\end{array}$ & $\begin{array}{l}-0.000 \\
(-1.91)^{* *}\end{array}$ & $\begin{array}{l}-0.000 \\
(-2.18)^{* *}\end{array}$ & $\begin{array}{l}-0.000 \\
(-3.49)^{*}\end{array}$ & $\begin{array}{l}-0.000 \\
(-5.18)^{*}\end{array}$ \\
\hline $\begin{array}{l}\text { Economic } \\
\text { Freedom }\end{array}$ & $\begin{array}{l}-0.18 \\
(-7.67)^{*}\end{array}$ & $\begin{array}{l}-0.17 \\
(-7.16)^{*}\end{array}$ & $\begin{array}{l}-0.21 \\
(-9.27)^{*}\end{array}$ & $\begin{array}{l}-0.15 \\
(-5.92)^{*}\end{array}$ & $\begin{array}{l}-0.13 \\
(-5.24)^{*}\end{array}$ & $\begin{array}{l}-0.20 \\
(-5.53)^{*}\end{array}$ & $\begin{array}{l}-0.19 \\
(-7.79)^{*}\end{array}$ & $\begin{array}{l}-0.19 \\
(-9.12)^{*}\end{array}$ \\
\hline $\begin{array}{l}\text { Rule of the } \\
\text { Law }\end{array}$ & $\begin{array}{l}-0.34 \\
(-9.60)^{*}\end{array}$ & $\begin{array}{l}-0.40 \\
(-10.77)\end{array}$ & $\begin{array}{l}-0.38 \\
(-11.15)\end{array}$ & $\begin{array}{l}-0.29 \\
(-7.70)^{*}\end{array}$ & $\begin{array}{l}-0.25 \\
(-6.84)^{*}\end{array}$ & $\begin{array}{l}-0.44 \\
(-6.98)^{*}\end{array}$ & $\begin{array}{l}-0.31 \\
(-8.54)^{*}\end{array}$ & $\begin{array}{l}-0.37 \\
(-11.36)^{*}\end{array}$ \\
\hline $\begin{array}{l}\text { Government } \\
\text { Expenditure }\end{array}$ & $\begin{array}{l}-0.04 \\
(-6.05)^{*}\end{array}$ & $\begin{array}{l}-0.04 \\
(-5.24)^{*}\end{array}$ & $\begin{array}{l}-0.04 \\
(-5.42)^{*}\end{array}$ & $\begin{array}{l}-0.04 \\
(-5.54) *\end{array}$ & $\begin{array}{l}-0.04 \\
(-4.97)^{*}\end{array}$ & $\begin{array}{l}-0.06 \\
(-5.19)^{*}\end{array}$ & $\begin{array}{l}-0.04 \\
(-5.18)^{*}\end{array}$ & $\begin{array}{l}-0.03 \\
(-4.14)^{*}\end{array}$ \\
\hline $\begin{array}{l}\text { Government } \\
\text { Stability }\end{array}$ & - & $\begin{array}{l}0.099 \\
(4.29)^{*}\end{array}$ & & & & & & \\
\hline $\begin{array}{l}\text { Investment } \\
\text { Profile }\end{array}$ & & & $\begin{array}{l}0.14 \\
(6.95)^{*}\end{array}$ & & & & & \\
\hline $\begin{array}{l}\text { Military in } \\
\text { Politics }\end{array}$ & & & & $\begin{array}{l}-0.09 \\
(-2.84)^{*}\end{array}$ & & & & \\
\hline $\begin{array}{l}\text { Bureaucracy } \\
\text { Quality }\end{array}$ & & & & & $\begin{array}{l}-0.34 \\
(6.71)^{*}\end{array}$ & & & \\
\hline Arm Trade & & & & & & $\begin{array}{l}0.00 \\
(2.01)^{*}\end{array}$ & & \\
\hline$H F I$ & & & & & & & $\begin{array}{l}0.00 \\
(1.84)^{*}\end{array}$ & \\
\hline Yr1989 & & & & & & & & $\begin{array}{l}-0.23 \\
(-2.08)^{* *}\end{array}$ \\
\hline Yr1994 & & & & & & & & $\begin{array}{l}-0.34 \\
(-3.18)^{*}\end{array}$ \\
\hline Yr1999 & & & & & & & & $\begin{array}{l}0.53 \\
(5.27)^{*}\end{array}$ \\
\hline Yr2004 & & & & & & & & $\begin{array}{l}0.82 \\
(7.93)^{*}\end{array}$ \\
\hline $\mathrm{R}^{2}$ & 0.55 & 0.57 & 0.59 & 0.56 & 0.59 & 0.63 & 0.50 & 0.66 \\
\hline Adjusted $\mathrm{R}^{2}$ & 0.54 & 0.56 & 0.58 & 0.55 & 0.58 & 0.62 & 0.49 & 0.65 \\
\hline F-Test & $\begin{array}{l}119.66 \\
(0.000)\end{array}$ & $\begin{array}{l}109.09 \\
(0.000)\end{array}$ & $\begin{array}{l}117.77 \\
(0.000)\end{array}$ & $\begin{array}{l}104.95 \\
(0.000)\end{array}$ & $\begin{array}{l}116.85 \\
(0.000)\end{array}$ & $\begin{array}{l}53.93 \\
(0.000)\end{array}$ & $\begin{array}{l}70.97 \\
(0.000)\end{array}$ & $\begin{array}{l}110.74 \\
(0.000)\end{array}$ \\
\hline Observation & 600 & 591 & 591 & 591 & 591 & 230 & 512 & 512 \\
\hline
\end{tabular}

(Notes) (i) The $t$-statistics are given in parentheses.

(ii) * indicate significance at $1 \%$ level,

** indicate significance at $5 \%$ level,

$* * *$ indicate significance at $10 \%$ level. 


\section{Conclusion}

The literature on causes of corruption has proliferated in recent years and now showing consensus on some causes of corruption although many of the causes remain controversial. For instance, Serra (2006) shows economic development, democracy, and political stability are the important variables of corruption. However, the literature has not yet examined the presence of nonlinearity in shaping the relationship between trade and corruption. Similarly, the importance of complimentary policy reforms in corruptionopenness nexus has not yet been examined.

Using a panel data set for 146 countries over the period 1984 2007, this study suggests that in linear specification, openness to trade is corruption increasing while in a nonlinear specification, its effect is negative. Furthermore, we argue and find empirical support to our proposition that this is not just openness to trade that can reduce corruption but there are complimentary policy reforms that cause a decline in corruption. The combined effect of trade openness and high bureaucracy quality is corruption reducing. Similarly, combined effect of trade openness and financial reforms is corruption reducing. In this study, government expenditures appear to have negative effect on corruption. Policy implications of this study are as follows:

- The government must ensure economic freedom to eradicate corruption that grips our national life.

- Since a low level of trade integration is not helping to control corruption, trade openness needs to be extensive for it to control corruption.

- Trade-oriented economies need to develop better domestic conditions such as financial reforms to take the advantage of trade as a channel to control corruption.

- Inflation is also one source of corruption, therefore, it needs to be kept within specified limits to reduce the corruption incidence.

- The role of government is effective in reducing corruption.

- The quality of bureaucracy is helpful in reducing corruption.

- It is recommended that government needs to pay its officials market-indexed salaries commensurate with their responsibility. 


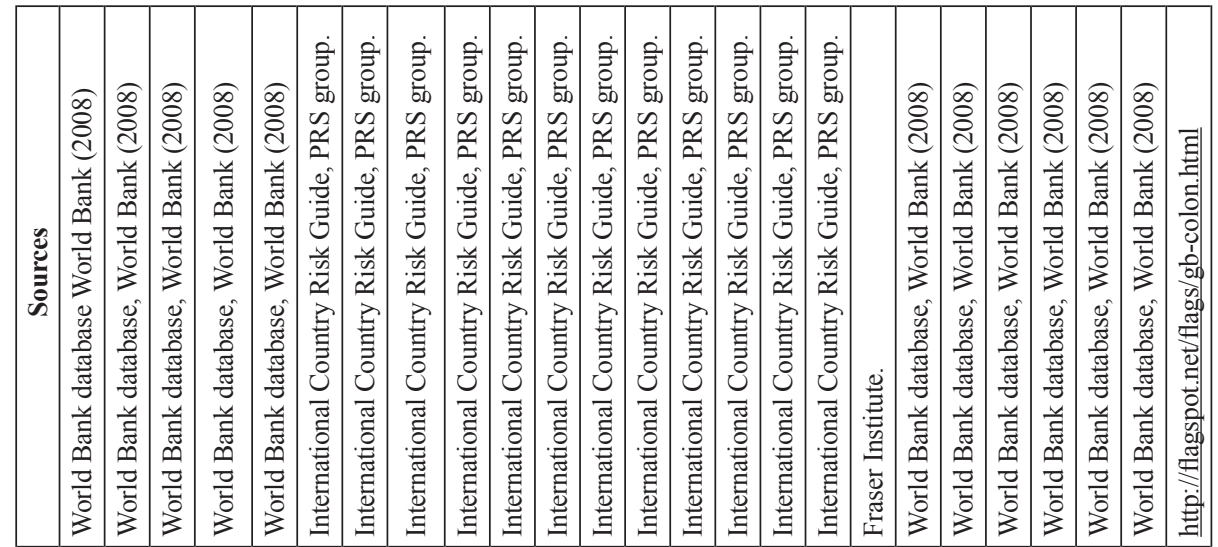

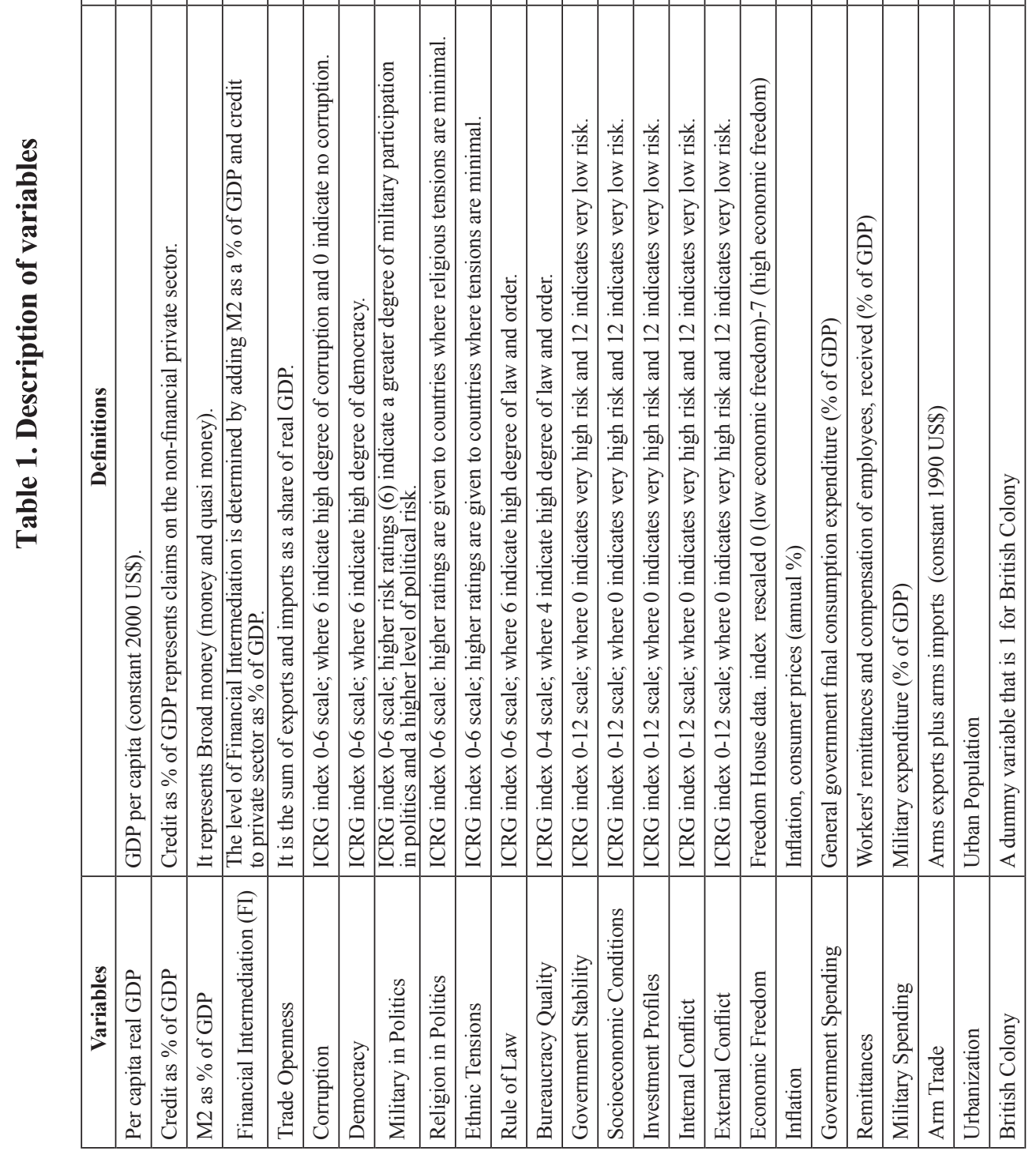


Received 30 January 2014, Revised 12 September 2014, Accepted 10 October 2014

\section{References}

Ades, Alberto, and Rafael Di Tella. "Rents, Competition, and Corruption." American Economic Review (1999): 982-993. http://www.jstor.org/stable/117169

Becker, Gary S. "Crime and Punishment: An Economic Approach." The Journal of Political Economy 76, no. 2 (1968): 169-217. http://www.jstor.org/stable/1830482

Berdiev, Aziz N., Yoonbai Kim, and Chun-Ping Chang. "Remittances and Corruption." Economics Letters 118, no. 1 (2013): 182-185. DOI: 10.1016/j.econlet.2012.10.008

Bhagwati, Jagdish N. "Directly Unproductive, Profit-Seeking (DUP) Activities." The Journal of Political Economy (1982): 988-1002. http://www.jstor.org/stable/1837129

Bhagwati, Jagdish N., and T. N. Srinivasan. "Revenue seeking: A Generalization of the Theory of Tariffs." The Journal of Political Economy (1980): 1069-1087. http://www. jstor.org/stable/1831156

Chang, Roberto, Linda Kaltani, and Norman V. Loayza. "Openness can be Good for Growth: The Role of Policy Complementarities." Journal of Development Economics 90, no. 1 (2009): 33-49. DOI: 10.1016/j.jdeveco.2008.06.011

Drabek, Zdenek, and Warren Payne. "The impact of Transparency on Foreign Direct Investment." Journal of Economic Integration 17, no. 4 (2002): 777-810. DOI: http:// dx.doi.org/10.11130/jei.2002.17.4.777

Elbahnasawy, Nasr G. "E-Government, Internet Adoption, and Corruption: An Empirical Investigation.” World Development 57 (2014): 114-126. DOI: 10.1016/ j.worlddev.2013.12.005

Foster, Edward, and Hugo Sonnenschein. "Price Distortion and Economic Welfare." Econometrica: Journal of the Econometric Society (1970): 281-297. http://www.jstor. org/stable/1913010

Gatti, Roberta. Corruption and Trade Tariffs, or A Case for Uniform Tariffs. Vol. 2216. World Bank Publications, 1999. DOI: 10.1596/1813-9450-2216 
Gatti, Roberta. "Explaining Corruption: Are Open Countries Less Corrupt?” Journal of International Development 16, no. 6 (2004): 851-861. DOI: 10.1002/jid.1115

Hisamatsu, Y. "Does Foreign Demand Affect Corruption?" Applied Economics Letters 10, no. 1 (2003): 1-2. DOI:10.1080/13504850210165838

International Country Risk Guide (ICRG). “A Business Guide to Political Risk for International Decisions” (New York: The PRS Group), 2008.

International Monetary Fund "International Financial Statistics Yearbook" International Monetary Fund, Washington DC. 2008.

Jovanovic, Miroslav N. "Is Globalisation Taking us for a Ride?." Journal of Economic Integration 25, no. 3 (2010): 501-549. DOI: http://dx.doi.org/10.11130/jei.2010.25.3.501

Krueger, Anne O. "The political Economy of the Rent-Seeking Society." The American Economic Rreview (1974): 291-303.http://www.jstor.org/stable/180888

Lipsey, Richard G., and Kelvin Lancaster. "The General Theory of Second Best." The Review of Economic Studies (1956): 11-32. http://www.jstor.org/stable/2296233

MacDonald, Ronald, and M. Tariq. Majeed. "Causes of Corruption in European Countries: History, Law, and Political Stability" No. 2011_24. 2011. http://www.gla. ac.uk/schools/business/research/publications/discussionpapers/2010/

Majeed, M. Tariq, and Ronald Macdonald. "Corruption and the Military in Politics: Theory and Evidence From Around the World." No. 2010_34. 2010. http://www.gla. ac.uk/schools/business/research/publications/discussionpapers/2010/

Majeed, M. Tariq, and Ronald MacDonald. "Corruption and Financial Intermediation in a Panel of Regions: Cross-Border Effects of Corruption.” (2011). http://www.gla.ac.uk/ schools/business/research/publications/discussionpapers/2011/

Pellegrini, Lorenzo. "Causes of Corruption: A Survey of Cross-Country Analyses and Extended Results." In Corruption, development and the environment, pp. 29-51. Springer Netherlands, 2011. DOI: 10.1007/978-94-007-0599-9_3

Rader, Trout. "The Welfare Loss from Price Distortions." Econometrica: Journal of the Econometric Society (1976): 1253-1257. http://www.jstor.org/stable/1914258

Suzuki, Yui, and Omer Gokcekus. "Intensity of Trade With the EU and Corruption in Africa." Journal of Economic Integration 28, no.4 (2013): 610-630. Available at SSRN 
2272108 (2013). DOI: http://dx.doi.org/10.11130/jei.2013.28.4.610

Tanzi, Vito. "Corruption around the World: Causes, Consequences, Scope, and Cures." Staff Papers-International Monetary Fund (1998): 559-594. http://www.jstor.org/ stable/3867585

Torrez, Jimmy. "The Effect of Openness on Corruption." Journal of International Trade \& Economic Development 11, no. 4 (2002): 387-403. DOI: 10.1080/09638190 22000014267

Transparency International. Global Corruption Report, 2005. http://www.transparency. org/publications/gcr.

Treisman, Daniel. "The Causes of Corruption: A Cross-National Study." Journal of Public Economics 76, no. 3 (2000): 399-457. DOI: 10.1016/S0047-2727(99)00092-4

Tyburski, Michael D. "Curse or Cure? Migrant Remittances and Corruption." The Journal of Politics (2014): 1-11. DOI: http://dx.doi.org/10.1017/S0022381614000279

Wei, Shang-Jin, and Andrei Shleifer. "Local Corruption and Global Capital Flows." Brookings Papers on Economic Activity 2 (2000): 303-346. http://www.jstor.org/ stable/2667361

World Bank (2001) http://www.worldbank.org/publicsector/anticorrupt/index.ctm.

World Bank. "World Development Indicators." 2008 (Washington DC: World Bank). http://data.worldbank.org/products/wdi

Yarbrough, Beth V., and Robert M. Yarbrough. "Economic Integration and Governance: The Role of Preferential Trade Agreements." Journal of International Economic Integration (1990): 1-20. http://www.jstor.org/stable/230000 

